\title{
日高変成帯南部の深成変成岩類 ${ }^{*}$
}

Plutonic and metamorphic rocks in the southern Hidaka metamorphic belt, Hokkaido

\section{高橋 浩 $^{1}$ 志村俊昭 $^{2}$ 加藤聡美 ${ }^{3}$}

\section{Yutaka Takahashi ${ }^{1}$,Toshiaki Shimura and Satomi Kato}

2018 年 1 月 29 日受付.

2018 年 5 月 16 日受理.

日本地質学会第 125 年学術大会 $(2018$ 年・札幌) 巡検 (F コース) 案内書

産業技術総合研究所地質情報研究部門

Research Institute of Geology and Geoinformation, Geological Survey of Japan (GSJ), National Institute of Advanced Industrial Science and Technology (AIST), 1-1-1 Higashi, Tsukuba, Ibaraki 305-8567, Japan 山口大学大学院創成科学研究科

Graduate School of Science and Technology for Innovation, Yamaguchi University, Yamaguchi 753-8512, Japan アポイ岳ジオパークビジターセンター

Mt. Apoi Geopark Visitor Center, Samani, Hokkaido 058-0004, Japan

Corresponding author: Y. Takahashi, takahashi-yutaka@aist.go.jp

(注) 本原稿のPDF カラー版が J-STAGE でご覧い ただけます。

https://www.jstage.jst.go.jp/browse/geosoc/-char/ja

\begin{abstract}
概 要
日高変成帯は島弧ないし大陸地殼の衝上断片と考えられており, 非変成 堆積岩類からグラニュライト相に達する高変成度変成岩類まで観察できる 世界的に見ても稀な地質体であり, 島弧ないし大陸地殼の成因を解明する ための絶好の対象となっている. 1990 年代〜2000 年代はじめまでに, 日 高変成帯の基本構造や発達史は確立されたかと思われた. しかし, 2006 年 以降, 変成岩類および深成岩類中のジルコンの $\mathrm{U}-\mathrm{Pb}$ 年代の報告によって, 日高変成帯下部層 (高変成度側) の主要変成作用の時期は $19 \mathrm{Ma}$ 頃であるこ とが明らかとなり, 従来の日高深成・変成作用の年代論 $(55 \mathrm{Ma}$ 頃の主要深 成・変成作用)の見直しが必要となった. また, 日高変成帯上部層(低変成 度側) は, 中の川層群と漸移関係にあり, 変成岩類の年代が 40〜 30 Ma 頃 を示すことから, 変成帯下部層とは別のより古い時代の変成作用を被った 地質体の可能性が浮かび上がってきた。つまり, 日高変成帯はこれまで, 古第三紀に形成された一連の高温型の変成帯と考えられてきたが, 最近の 研究成果に基づけば，新第三紀のグラニュライトを含む高変成度変成岩類 と古第三紀に形成された角閃岩相から緑色片岩相で非変成中の川層群堆積 岩類に移化する変成岩類とが接合した地質体である可能性がある.

この巡検では, 日高山脈南部地域において, 日高変成帯上部層および下 部層を構成する変成岩類および上部層に貫入する深成岩類を観察し, 最新 の研究成果を紹介する.
\end{abstract}

\section{Keywords}

日高帯, 日高変成帯, 中の川層群, S タイプトーナル岩, ヌピナイ花崗岩, 幌満かんらん岩体, 音調津深成岩体

Hidaka Belt, Hidaka Metamorphic Belt, Nakanogawa Group, S-type tonalite, Nupinai Granite, Horoman Peridotite Complex, Oshirabetsu Plutonic Complex

地形図

$1: 25,000$ 「トヨニ岳」, 「楽古岳」,「様似」, 「庶野」, 「日高目黒」,「音調津」

\section{見学コース}

[1 日目] (大樹町, 広尾町, 浦河町, 様似町) 8:00 北海道大学出発 $\rightarrow[1]$ 天馬街道二股橋付近 $\rightarrow[2]$ メナシュンベツ川標高 $294 \mathrm{~m}$ 二股付近 $\rightarrow[3]$ 様似町役場 $\rightarrow$ 様似町 (泊)

[2 日目]（様似町, えりも町, 広尾町, 大樹町) 様似郡様似町 $\rightarrow[4]$ アポイ岳ジオパークビジターセンター $\rightarrow[5]$ ルーラン海岸 $\rightarrow[6]$ 音調津海岸 $\rightarrow$ 新千歳空港 $(17: 00)$

\section{見学地点}

Stop 1 (42 $\left.22^{\prime} 52^{\prime \prime} \mathrm{N}, 143^{\circ} 3^{\prime} 32^{\prime \prime} \mathrm{E}\right)$

Stop $2\left(42^{\circ} 15^{\prime} 20^{\prime \prime} \mathrm{N}, 143^{\circ} 3^{\prime} 30^{\prime \prime} \mathrm{E}\right)$

Stop $3\left(42^{\circ} 7^{\prime} 39^{\prime \prime} \mathrm{N}, 142^{\circ} 56^{\prime} 0^{\prime \prime} \mathrm{E}\right)$

Stop $4 \quad\left(42^{\circ} 6^{\prime} 42^{\prime \prime} \mathrm{N}, 142^{\circ} 59^{\prime} 19^{\prime \prime} \mathrm{E}\right)$

Stop $5\left(42^{\circ} 1^{\prime} 37^{\prime \prime} \mathrm{N}, 143^{\circ} 17^{\prime} 13^{\prime \prime} \mathrm{E}\right)$

Stop $6\left(42^{\circ} 10^{\prime} 4^{\prime \prime} \mathrm{N}, 143^{\circ} 19^{\prime} 44^{\prime \prime} \mathrm{E}\right)$
天馬街道二股橋上流駐車場付近, ヌピナイ花崗岩

メナシュンベツ川標高 $294 \mathrm{~m}$ 二股付近, 日高変成帯下部変成岩層グラニュライト

様似町役場, かんらん岩広場「アポイの鼓動」

アポイ岳ジオパークビジターセンター

ルーラン海岸, 日高変成帯上部層片麻岩類と堇青石トーナル岩

音調津海岸, 音調津深成岩類 


\section{は じめに}

日高変成帯は新生代に形成された島弧ないし大陸地殼の衝 上断片と考えられており (Komatsu et al., 1983; 小松ほか, 1986 など), 非変成堆積岩類 (中の川層群)からグラニュラ イト相に達する高変成度変成岩類まで観察できる世界的に見 ても稀な地質体である. 日高変成帯の研究は, 1980 年代〜 1990 年代にかけて急速に発展し(小松ほか, 1986; Osanai et al., 1991, 1992; Shimura et al., 1992; Komatsu et al., 1994 など), 日高変成帯の基本構造やその発達史が詳細に 研究されていつた.

日高変成帯の変成・火成作用の時期を示す年代として, グ ラニュライトとグラニュライトが部分溶融して形成されたと 考えられている $\mathrm{S}$ タイプトーナル岩を用いた $\mathrm{Rb}-\mathrm{Sr}$ 全岩ア イソクロン年代の $56 \mathrm{Ma}$ (Owada et al., 1991) と $55 \mathrm{Ma}$ (大 和田ほか, 1992), および I タイプトーナル岩の $\mathrm{Rb}-\mathrm{Sr}$ 全岩 アイソクロン年代の $51 \mathrm{Ma}($ Owada et al., 1997)が報告さ れた. これらのことから, 日高変成帯の主要深成・変成作用 は 55 Ma 頃に起きたとされた (Owada et al., 1991, 1997; Osanai et al., 1992; 大和田ほか, 1992). その後, 2000 年 代初め頃までには, 日変成帯の形成史は総括され(豊島ほか, 1997; Owada et al., 2003; 小山内ほか, 2006 など), 確立 されたかに思われた。

しかし 2006 年以降から, 二次イオン質量分析計を用いた ジルコン U-Pb 年代が報告されはじめ (Usuki et al., 2006; Kemp and Shimura, 2006; Kemp et al., 2007), 日高変成 帯の年代論の再考が必要となつた. 例えば, Usuki et al. (2006) は変成帯中部および南部の 3 地点から採取した泥 質グラニュライトのジルコンから 23.7〜 17.2 Ma の年代を 報告した. さらにKemp et al. (2007) は, 変成帯北部の 1 地点から採取した斑れい岩, 2 地点の $\mathrm{S}$ タイプトーナル岩, 2 地点の泥質グラニュライト捕獲岩, 変成帯中部の 2 地点か ら採取した泥質グラニュライト, 1 地点の苦鉄質変成岩のジ ルコンから，いずれも約 $19 \mathrm{Ma}$ の年代を報告した.これに より日高変成帯下部層 (高変成度側)の主要変成作用の時期は $55 \mathrm{Ma}$ 頃ではなく, $19 \mathrm{Ma}$ 頃である事が確実となった. さ らに, 班れい岩マグマもこれと同時期に活動していたことが 明らかとなった(Kemp et al., 2007). この $19 \mathrm{Ma}$ 頃の熱 イベントの原因は, オホーツク海盆・日本海盆の拡大に伴う アセノスフェアの上昇に対応すると考えられている $(\mathrm{Kimu}-$ ra, 1986; Usuki et al., 2006; Kemp et al., 2007). さらに Kemp et al. (2007) は, 変成帯北部と中部の 2 地点から採 取した Iタイプトーナル岩と花崗岩から約 $37 \mathrm{Ma}$ の年代を 報告した. これにより日高変成帯は 2 回の熱パルスを経験 していることが初めて示された.この 2 回の顕著な熱パル スの存在は, 日高変成帯の広い範囲から報告されてきている (志村ほか, 2015; 小島ほか, 2015).

また, 日高変成帯上部層は, 中の川層群の堆積岩類と漸移 関係にあり, 変成岩類の年代が 40～30 Ma 頃を示すことか ら (佐伯ほか, 1995; 小野, 2002; 高橋ほか, 2017), 変成帯 下部層のグラニュライト相変成作用に先行する 1 回目の熱
パルスによる変成作用を被つた地質体の可能性が浮かび上 がつてきた. つまり, 日高変成帯はこれまで, 古第三紀に形 成された一続きの高温型の変成帯 (同一時期に形成された累 進変成带, 単一の島弧・大陸地殼) と考えられてきたが, 最 近の研究成果に基づくならば，志村ほか (2015)が論じたよ うに, 新第三紀のグラニュライトを含む高変成度変成岩類と 古第三紀に形成された角閃岩相〜緑色片岩相で非変成中の川 層群に移化する変成岩類とが接合した地質体である可能性が ある.

我々は, これまで, 日高変成帯の深成・変成岩類および中 の川層群のフィールドワークに基づく地質学的研究を行って きた (志村, 1992; 高橋, 1992 など). この巡検では, 以上の 観点から, 日高山脈南部地域において, 日高変成帯上部層お よび下部層を構成する変成岩類および上部層に貫入する深成 岩類を観察し, 北海道中軸帯および日高変成帯の構造発達史 に関する最新の研究成果を紹介したい. なお，本論で使用す る鉱物名の略号は Whitney and Evance(2010)に従つた.

\section{地 質 概 要}

\section{1. 北海道中軸帯の地質概説}

北海道の先新第三紀地質帯は, 西から東に向かって, 渡島 帯, 空知-エゾ帯, 日高帯, 常吕帯および根室帯に区分され ている(Ueda, 2016; Fig. 1)。これらの地質帯のうち渡島帯 と根室帯を除いた北海道中央部を構成する空知一エゾ帯, 日 高帯および常呂帯は北海道中軸帯と呼ばれてきた(橋本, 1978 など)。渡島帯および空知ーエゾ帯は西側の本州島弧一 海溝系の北方延長であり, 常呂帯と根室帯は古千島島弧一海 溝系に属している(Ueda, 2016). 日高帯は西側の本州弧側 の島弧海溝系と, 東側の古千島弧側の島弧一海溝系の地質要 素を含んでおり (七山, 1992 など), 本州弧と千島弧との衝 突带と考えられている (Kimura, 1996; 木村・楠, 1997 な ぞ). 日高変成帯は, 日高帯に属し, 北海道中央南部に位置 する日高山脈周辺に存在し, 南北約 $140 \mathrm{~km}$ 最大幅約 $20 \mathrm{~km}$ で, 北北西-南南東方向に延びた細長い形態を示す. 各種変成岩類 (日高変成岩類) および深成岩類 (日高深成岩類) より構成され, 島弧地殼の断面が露出した地質体と考えられ ている(小松ほか, 1986; Komatsu et al., 1989 など).

\section{2. 日高変成帯の地質概説}

日高変成帯は, 日高変成岩類および日高深成岩類からな り, 日高変成岩類は, 変成帯の西側に分布する苦鉄質変成岩 類を主とし少量の砂泥質変成岩類が挟在する下部変成岩層 （グラニュライト相〜角閃岩相）とその東側に分布し砂泥質変 成岩類を主とする上部変成岩層 (角閃岩相〜緑色片岩相)に区 分されている(小山内, 1985; Osanai et al., 1986; 小松ほ か, 1986; Osanai et al., 1991）（Figs. 2, 3）. 上部層変成 岩類は東側に分布する中の川層群とは漸移関係にある(小山 内, 1985; 高橋, 1992). 変成度は西側ほど相対的に高く, グラニュライト相に達する各種変成岩類が帯状に分布してい る. 日高深成岩類は, 超苦鉄質岩類, 斑れい岩〜閃緑岩類お よび花崗岩類に区分できる. 花崗岩類は, その鉱物組み合わ せと母岩の変成岩類の変成度から, 西側ほど深部相であると 
Sorachi-Yezo Belt

Cretaceous clastic deposits (Yezo Supergroup) [II Jurassic basalt \&

Early Cret. siliceous/volcanic deposits (Sorachi G.)

Ultramafic rocks

$\approx$ Kamuikotan high-P/T Metamorphics

E, Early Cretaceous accretionary complex (Naizawa Complex)

Late Cret. accretionary complex (Horobetsugawa Complex)

䎴冊 Mid-Cretaceous ophiolite (Poroshiri Ophiolite)

Oshima Belt

Early Cretaceous volcanics \& sediments

(Rebun \& Kabato groups)

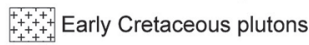

Jurassic accretionary complex

$x$

Sorachi-Yezo Belt

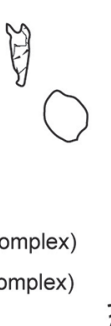

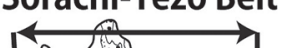

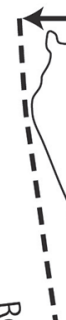

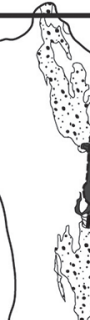

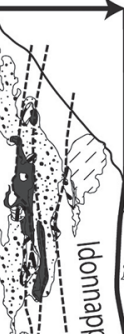
Tokoro Belt
Late Cret. clastic deposits (Saroma Group)
iN. Late Cret.accretionary complex (Nikoro Group)

Hidaka Belt Nemuro Belt

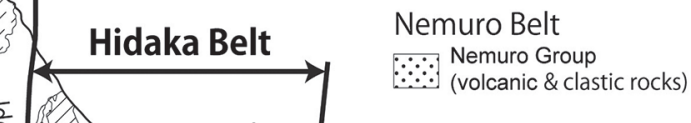

$\because \because \begin{aligned} & \text { Nemuro Group } \\ & \text { (volcanic \& clastic rocks) }\end{aligned}$

Tokoro

Belt
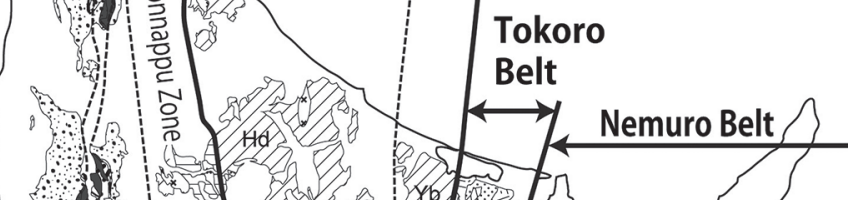

(c)
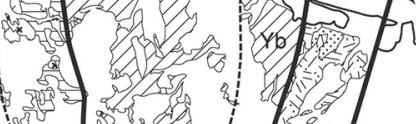


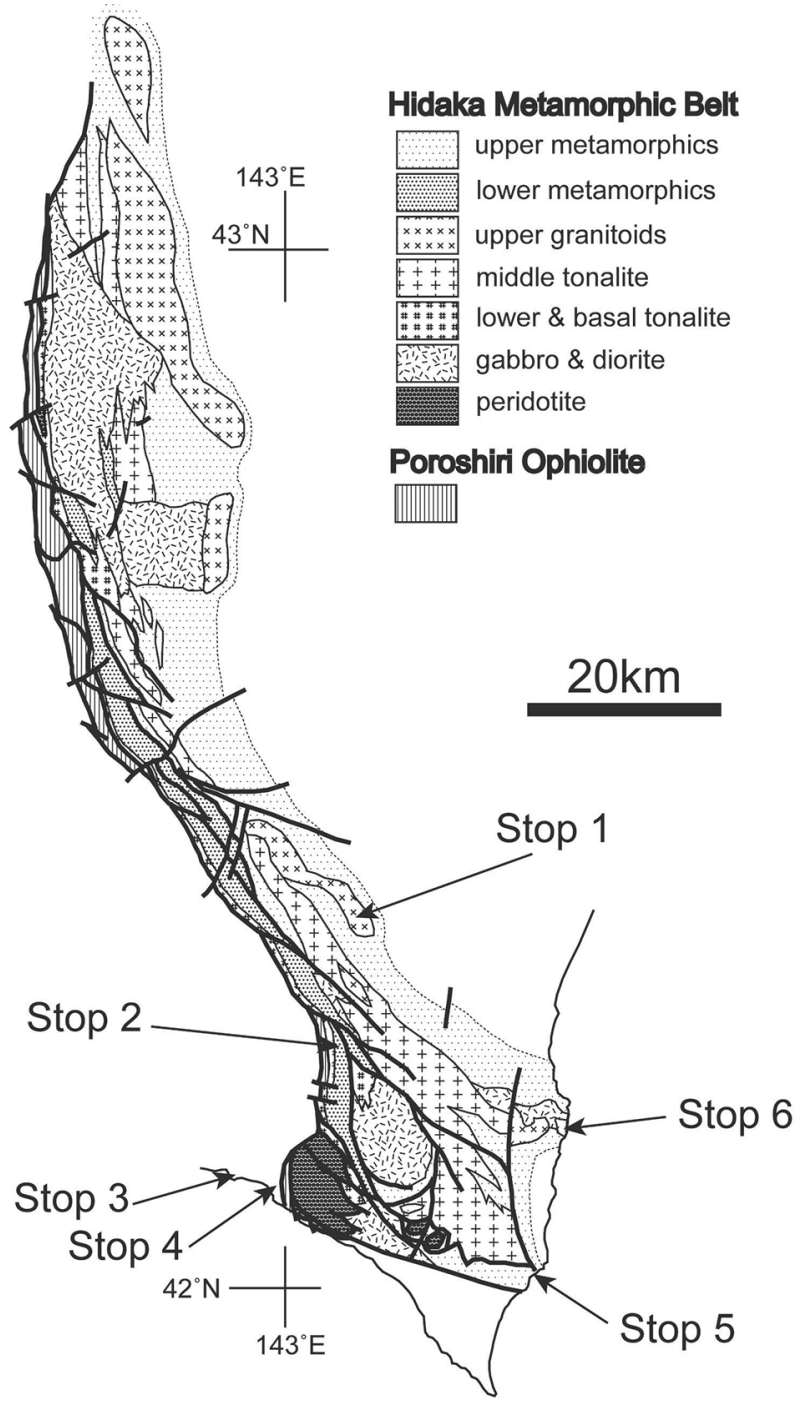

Fig. 2. Geological map of the Hidaka metamorphic belt, modified after Komatsu et al. (1986).

岩の黒雲母 $\mathrm{K}-\mathrm{Ar}$ 年代), 41 31 Ma (角閃岩の角閃石 K$\mathrm{Ar}$ 年代), 南西部において 19 $17 \mathrm{Ma}$ (泥質変成岩の黒雲母 $\mathrm{K}-\mathrm{Ar}$ 年代)を示す. また, 札楽古川におけるホルンフェル スのジルコンフィッショントラック年代は, 誤差が大きいも のの, $40 \mathrm{Ma}$ および $39 \mathrm{Ma}$ である(小野, 2002). したがつ て，上部層変成作用の年代はおよそ 40〜 30 Ma と考えられ るが, $\mathrm{K}-\mathrm{Ar}$ 年代やフィッショントラック年代は冷却年代を 示すため, 変成作用そのものの年代を示すと考えられている ジルコン $\mathrm{U}-\mathrm{Pb}$ 年代測定が重要である. そこで, 高橋ほか （2017）は, 上部層変成岩類が広く分布する猿留川の上部層 片麻岩および札内川の上部層片麻岩中のジルコンを分離し, レーザー照射型誘導結合プラズマ質量分析装置(LA-ICP$\mathrm{MS})$ を用いて U-Pb 年代測定を行った. 分離したジルコン にはすべて再結晶リムが存在する (Fig. 4a, 4b)，再結晶リ ムは, 低い $\mathrm{Th} / \mathrm{U}$ 比 $(0.01 \sim 0.09)$ を示しており, 変成作用 によって形成されたものと解釈された. 猿留川の分析結果は 残念ながらコンコーダント年代は得られなかったが，札内川

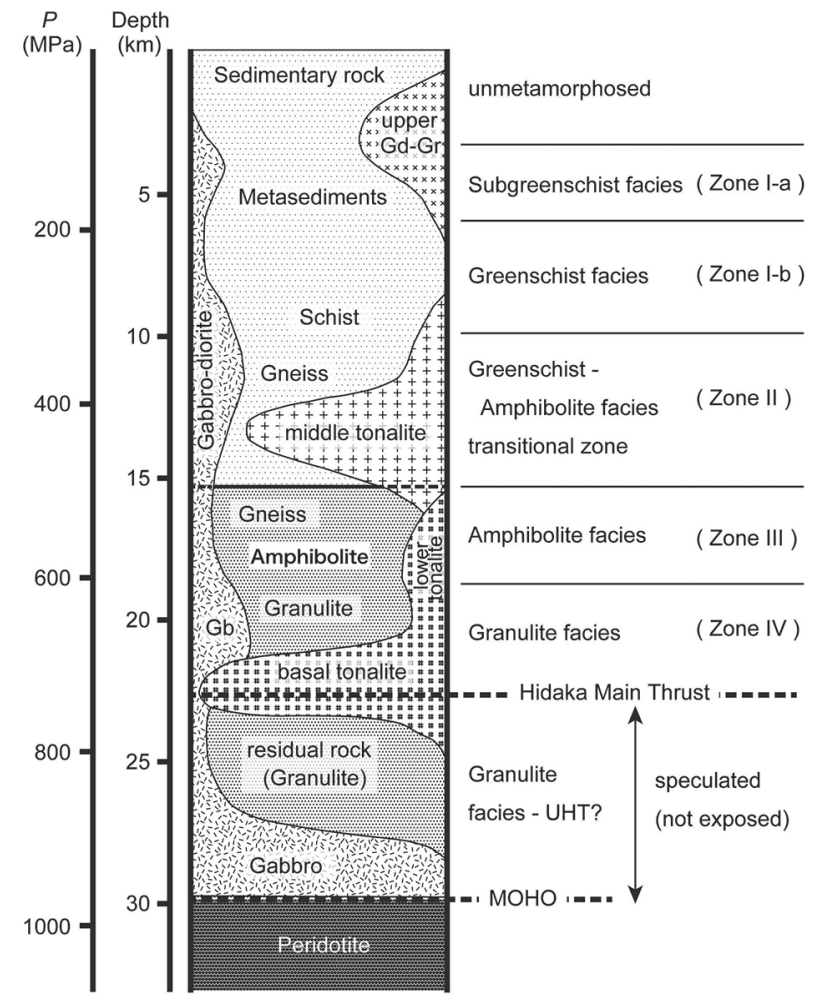

Fig. 3. Schematic columnar section of the Hidaka metamorphic belt, modified after Komatsu et al. (1986).

の片麻岩中のジルコン分析ではコンコーダント年代が得られ た (高橋ほか, 2017)。札内川の片麻岩中のジルコン再結晶リ ムの最若粒子集団 (4 試料) 加重平均年代は 39.6 $0.9 \mathrm{Ma}$ で あった. 一方, コアの最若粒子集団 (6 試料)加重平均年代は $53.1 \pm 0.9 \mathrm{Ma}$ で, その他に $70 \mathrm{Ma}$ 頃 (2 試料), $146 \mathrm{Ma}(1$ 試料), $200 \mathrm{Ma}$ 頃 (4 試料), $458 \mathrm{Ma}$ (1 試料)のコンコーダ ント年代が認められ，いずれも高い Th/U 比 $(0.36 \sim 1.11)$ を示しており, これらは黒雲母片麻岩の原岩である堆積岩の 後背地における火成作用の年代を示すと考えられた. 再結晶 リムの 39.6 $\pm 0.9 \mathrm{Ma}$ は変成作用の年代と解釈され, その熱源 は, 変成帯上部層に広く分布するトーナル岩類(ジルコン U$\mathrm{Pb}$ 年代は $37 \mathrm{Ma}$ 頃, Kemp and Shimura, 2006; [URL1])に 求められた.

\section{2 日高深成岩類 日高変成帯の深成岩類は, 超苦鉄質岩類,} 斑れい岩〜閃緑岩類および花崗岩類に区分できる. 超苦鉄質 岩類は, 変成帯南部にまとまって分布するほか, 日高主衝上 断層に沿つて断続的に分布する. 斑れい岩類は, 変成帯の北 部と南部にまとまって分布している, 花崗岩類は, 変成岩包 有物を多量に含夕全体的に不均質な岩相を呈するトーナル岩 類とその東側に分布する塊状の花崗岩〜花崗閃緑岩からな る. これらの花崗岩類は, その鉱物組み合わせと母岩の変成 岩類の変成度から, 西側ほど深部相であると考えられ, 最下 部トーナル岩, 下部トーナル岩, 中部トーナル岩および上部 花崗岩〜花崗閃緑岩に区分されている(小松ほか, 1986; 志 村, 1992; Shimura et al., 1992, 2004). 最下部トーナル岩 

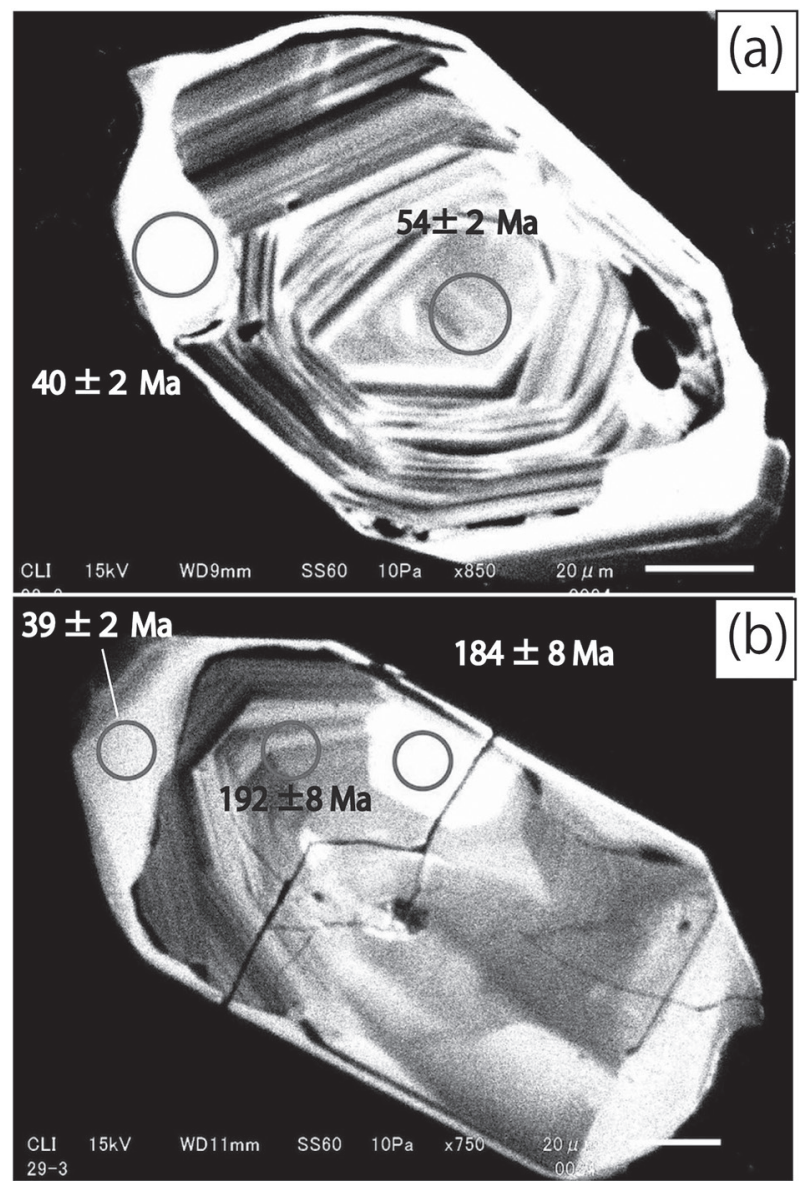

Fig. 4. U-Pb ages of zircon grains within the biotite gneiss of Satsunai River, plotted on $(a, b)$ cathodoluminescence images.

は, グラニュライト相の下部変成岩層に貫入しており, 主に 黒雲母直方輝石ざくろ石 (董青石) トーナル岩からなり, マイ ロナイト化していることが多い。 下部トーナル岩は, 角閃岩 相の下部変成岩層に貫入しており, 主に黒雲母直方輝石董青 石トーナル岩および黒雲母ざくろ石董青石トーナル岩からな る. 中部トーナル岩は, 緑色片岩相〜角閃岩相の上部変成岩 層中に貫入しており, 主に黒雲母トーナル岩, 白雲母黒雲母 トーナル岩および堇青石白雲母黒雲母トーナル岩よりなり, 角閃石黒雲母トーナル岩を伴う. 上部花崗岩〜花崗閃緑岩 は, 緑色片岩相の上部変成岩層および非〜弱変成の中の川層 群堆積岩層中に貫入しており, (角閃石) 黒雲母花崗岩〜花崗 閃緑岩からなる(小松ほか, 1986; 志村, 1992)。しかし, 近 年, これらの花崗岩類や斑れい岩類中のジルコン $\mathrm{U}-\mathrm{Pb}$ 年 代が報告され, 最下部トーナル岩で $19 \mathrm{Ma}$ 前後, 中部トー ナル岩で $37 \mathrm{Ma}$ 前後, 上部花崗岩〜花崗閃緑岩で $19 \mathrm{Ma}$ および $37 \mathrm{Ma}$ 前後の年代が報告され，2 回の火成作用が あったと考えられており (Kemp and Shimura, 2006; Kemp et al., 2007), 日高変成带全域の火成作用について 見直しが必要となっている.

日高変成帯南部地域には, 超苦鉄質岩類, 斑れい岩〜閃緑 岩類および花崗岩類が広く分布している. 超苦鉄質岩類は幌
満川下流域に南北 $10 \mathrm{~km} \times$ 東西 $8 \mathrm{~km}$ に及ぶ幌満岩体 $(\mathrm{Ni}-$ ida, 1974; 新井田・高澤, 2007 など) と二カンベツ川および アベヤキ川に小規模岩体が存在する (在田ほか, 1978 など). 斑れい岩〜閃緑岩類は, 幌満川上流に広く分布するオピラル カオマップ岩体 (本間, 1997) およびその南方のニカンベッ川 流域に分布する角閃石斑れい岩(在田ほか, 1978), 二オベツ 川上流に分布する二オべツ岩体 (大和田ほか, 2006), 音調津 周辺に分布する音調津岩体 (橋本・武田, 1960) および野塚川 上流に分布する小規模閃緑岩体(松井ほか, 1974)が存在す る.

南部日高山脈脊梁部には, 小松ほか (1986)で中部トーナ ル岩とされた片麻岩包有岩を多量に含み不均質な岩相を呈す る董青石黒雲母トーナル岩が広く分布しており, 均質な岩相 を呈する角閃石黒雲母トーナル岩および黒雲母トーナル岩を 伴う. 楽古岳岩体は, 楽古岳(標高 $1,471 \mathrm{~m}$ ) を中心に, 山 脈主稜線に沿って北西-南東方向に幅約 $5 \mathrm{~km}$, 長さ $30 \mathrm{~km}$ 程の岩体として分布し, 中部トーナル岩体では最大の規模を 示す. 豊似岳岩体は, 楽古岳岩体の南方の豊似岳(標高 1,105 m) 周辺に分布しており, 南方の黒雲母片麻岩の上にナップ としてのし上げている(大和田, 1989). 主に董青石黒雲母 トーナル岩からなり, 岩体北部で角閃石黒雲母トーナル岩に 貫入されている(大和田, 1989).

\section{見 学 地 点}

\section{Stop 1 ヌピナイ花崗岩}

[地形図] $1: 25,000\lceil$ 「当二岳」

[位 置] $42^{\circ} 22^{\prime} 52^{\prime \prime} \mathrm{N}, 143^{\circ} 3^{\prime} 32^{\prime \prime} \mathrm{E}$ (Fig. 5a)

[説明] ヌピナイ花崗岩(秋葉ほか, 1975) は, ヌピナイ川上 流から豊似川上流にかけて, 最大幅 $2 \mathrm{~km}$, 長さ $13 \mathrm{~km}$ 程 の北西一南東方向に伸張した形態で分布する塊状で均質な角 閃石黒雲母花崗岩であり, ほとんど包有岩を含まない(Fig. 6). 本岩は, 中-細粒で, 角閃石, 黒雲母, 石英, 斜長石, カリ長石からなり, 少量の不透明鉱物を含み, 褐れん石が認 められることがある (Fig. 7).

ヌピナイ花崗岩体は, 貫入深度による分類では上部花崗岩 に分類される. Kemp et al. (2007) は, ヌピナイ花崗岩のジ ルコン $\mathrm{U}-\mathrm{Pb}$ 年代を測定し $37.5 \mathrm{Ma}$ を報告した. この年代 は日高変成帯に広く分布する中部トーナル岩のジルコンU$\mathrm{Pb}$ 年代 (Kemp and Shimura, 2006; [URL1]) と同じであ り, 上部花崗岩である日勝岩体のジルコン $\mathrm{U}-\mathrm{Pb}$ 年代であ る $19 \mathrm{Ma}(J a h n$ et al., 2014) とは異なる.

\section{Stop 2 日高変成帯下部層グラニュライト}

[地形図] $1: 25,000$ 「楽古岳」

[位 置 $] 42^{\circ} 15^{\prime} 20^{\prime \prime} \mathrm{N}, 143^{\circ} 3^{\prime} 30^{\prime \prime} \mathrm{E}$ (Fig. 5b)

[説 明] メナシュンベツ川の河岸の露頭で, 日高変成帯の変 成分帯の IV 帯 (グラニュライト相)に相当する変成岩を観察 する. ここに露出する岩相の多くは苦鉄質変成岩(褐色角閃 石角閃岩, 直方輝石角閃石グラニュライト)であるが, 部分 的に数 $10 \mathrm{~cm}$ 程度の厚さの泥質变成岩 (ザクロ石堇青石グラ ニュライト)が挟在する. ザクロ石董青石グラニュライトは, 


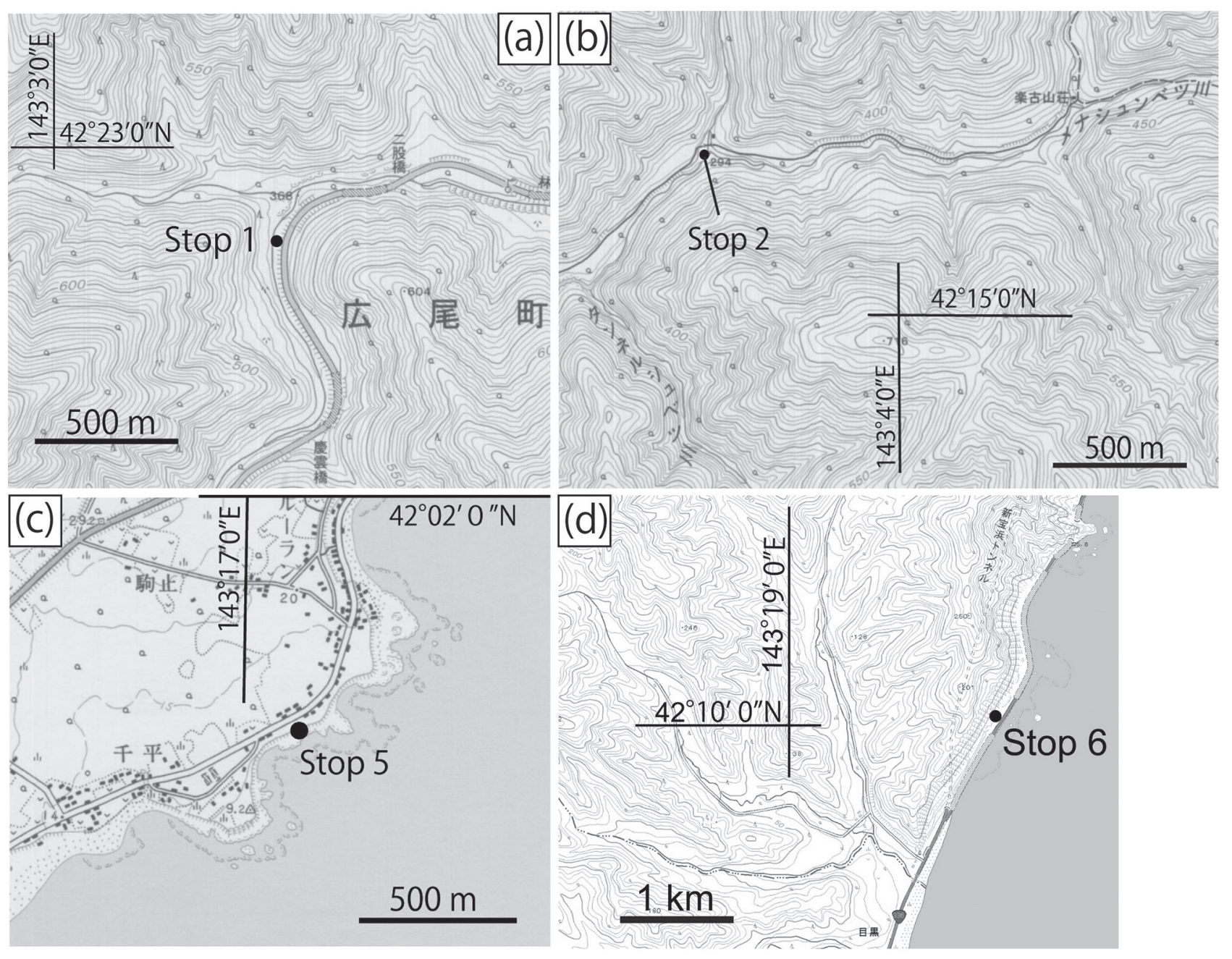

Fig. 5. Detailed topographic maps of the observation sites during the excursion (stops 1, 2 and 5) were taken from the topographic maps (scale 1: 25,000) of (a) "Toyonidake", (b) "Rakkodake", and (c) "Shoya" (Geographic Information Authority of Japan). (d) Detailed topographic map of Stop 6 in Hidakameguro area (topographic map, scale 1: 25,000) was taken from "Chiri-in Chizu” (https://maps.gsi.go.jp, Geographic Information Authority of Japan).

主にざくろ石，堇青石，珪線石，斜長石，石英から構成され (Fig. 8), 少量のカリ長石, イルメナイト, 磁硫鉄鉱, モナ ズ石，ジルコン，アパタイトを含む．ザクロ石と董青石は 2 $\mathrm{mm} \sim 1 \mathrm{~cm}$ 程度の斑状変晶として産する. 珪線石は黒雲母 とともに片理を形成するか, 堇青石内に包有されて産する. なお, Osanai and Owada(1990) はこの付近の露頭の泥質 グラニュライトから十字石を記載している. また, Usuki et al.(2006)はこの付近の泥質グラニュライトから $19.1 \mathrm{Ma}$ のジルコン $\mathrm{U}-\mathrm{Pb}$ 年代を報告している.

\section{Stop 3 かんらん岩広場「アポイの鼓動」}

[地形図] $1: 25,000$ 「様似」

[位 置 $] 42^{\circ} 7^{\prime} 39^{\prime \prime} \mathrm{N}, 142^{\circ} 56^{\prime} 0^{\prime \prime} \mathrm{E}$

[説明]様似町役場の前庭に「アポイの鼓動」かんらん岩広場 がある (Fig. 9). ここには噴水の周辺にかんらん岩の大きさ が 1〜2.5 m の研磨された大型標本が展示されていて, 野外 博物館になっている. かんらん岩とともに日高山脈をつくる
深成岩 (トーナル岩, かんらん石はんれい岩)や下部地殼を構 成するグラニュライト相変成岩もある. ここで観察できる幌 満かんらん岩体の岩石は, ダナイト, ハルツバージャイト, レルゾライト, 斜長石レルゾライト, 規模の大きい Type I (GB I) 苦鉄質岩など, さまざまである.

日高山脈には, 日高主衝上断層に沿って大小 10 のかんら ん岩体がある(Reseach Group of Peridotite Intrusion, 1967; 黒田・田崎, 1969; 小松, 1977). その中でも, 幌満 かんらん岩体に代表されるシリーズのかんらん岩(Miyashita and Niida, 1981)は, 日高変成帯の上部マントルに由来 する基底部を構成する. 日高変成帯のかんらん岩は, 一般に 蛇紋岩化作用などの加水変質をうけておらず, 新鮮な上部マ ントル鉱物からできている. 幌満かんらん岩体は, アポイ岳 〜ピンネシリから幌満川下流〜中流域, さらに東の坊主山周 辺にかけて分布し, 東西約 $8 \mathrm{~km}$, 南北約 $10 \mathrm{~km}$ に及ぶ(舟 橋・猪木, 1956). 緩やかに湾曲した厚い板状の岩体からな り，その厚さは約 $3,000 \mathrm{~m}$ と見積もられる (Niida, 1974, 


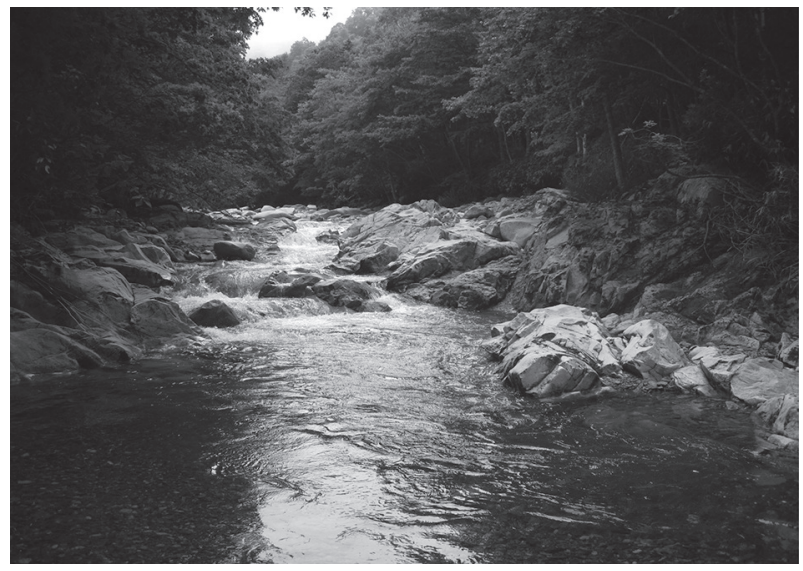

Fig. 6. The Nupinai Granite in the upper reaches of the Toyoni River, near Futamata bridge.

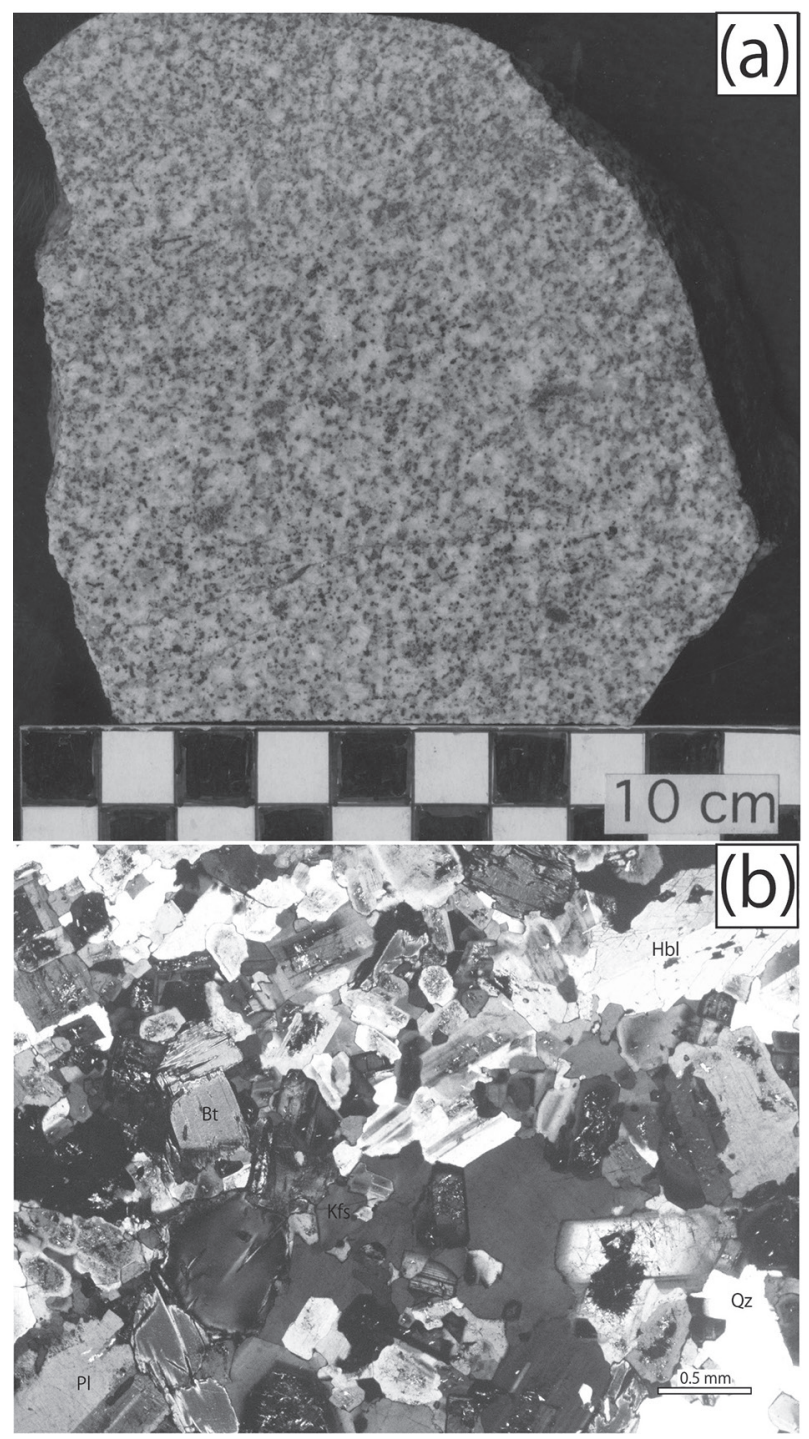

Fig. 7. (a) Polished slab and (b) photomicrograph (crossed polarized light) of the Nupinai Granite.

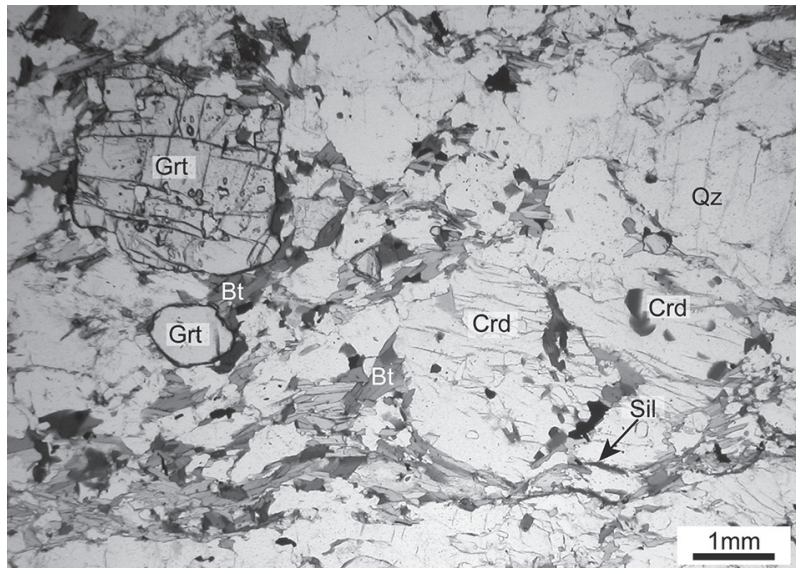

Fig. 8. Photomicrograph (plane polarized light) of the pelitic granulite from Yoshikawa the Menashunbetsu River.

1984）。巨大な超苦鉄質岩体は「幌満かんらん岩体」として世 界的に有名である. Yoshikawa et al. (1993)により金雲母 の $\mathrm{Rb}-\mathrm{Sr}$ 年代として $23 \mathrm{Ma}$ が, Kaneoka et al. (2001)に よって金雲母の ${ }^{40} \mathrm{Ar}-{ }^{39} \mathrm{Ar}$ 年代として 20.6 Ma が報告され ている. これらは金雲母を形成したメタソマティズムの時期 と考えられている(Yoshikawa et al., 1993; Kaneoka et al., 2001). かんらん岩広場東側にある箱の中にパンフレッ 卜を常設しているので, 晴れた日には東に見えるアポイ岳を 眺めながら観察してほしい.

以下に,「アポイの鼓動」に展示されている岩石について解 説する.

（1）ダナイト(Fig. 9 の A1〜A4） 幌満かんらん岩体の岩石 試料である，この岩石と同等の岩石は，新井田・高澤 (2007) で報告されており, 幌満川中流にある支流(記念物の沢)の合 流点付近などに分布する. 上部マントルを通過した玄武岩質 マグマの通路(マグマチャネル)でできたキュムレイトである と考えられている(Takahashi, 1992). 主としてかんらん石, スピネルから構成され, 少量の直方輝石, 単斜輝石, 稀にか んらん石巨晶を含むことがある.

(2)ハルツバージャイト(Fig. 9 の C, D, E, F) 幌満かん らん岩体の岩石試料である. 主としてかんらん石, 直方輝 石, 少量の単斜輝石, スピネルから構成される. 上部マント ルで玄武岩質マグマを生じ，マグマ成分に枯渇した融け残り かんらん岩であると考えられている(新井田・高澤, 2007).

(3)レルゾライト(Fig. 9 の H, I, K, W) 幌満かんらん岩 体の岩石試料である. この岩石と同等の岩石は新井田・高澤 (2007) で報告されており, 幌満川のゴヨウマツ記念碑付近 などに分布する. 主としてかんらん石, 直方輝石, 単斜輝石 から構成される. 玄武岩質マグマ成分にやや枯渇した融け残 りかんらん岩であると考えられる(例えば, Takazawa et al., 2000). レルゾライトをよく見ると, 赤紫色の薄層が多数含 まれている.これはスピネル, 直方輝石, 単斜輝石からなる 細粒結晶集合層である. この薄層には, 粒状の形をした粒径 $1 \mathrm{~mm}$ 程度の直方輝石一単斜輝石一スピネルシンプレクタイ 

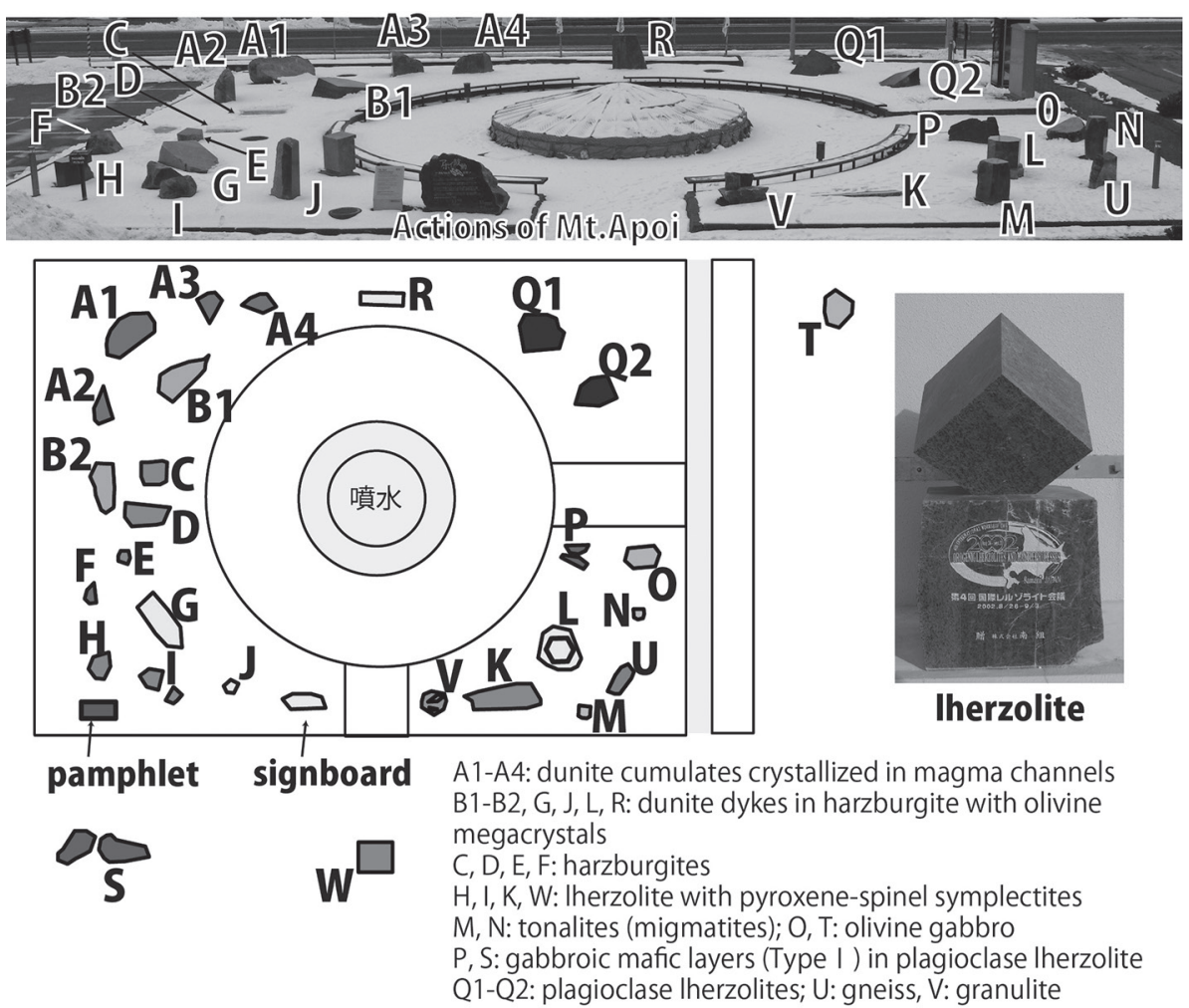

Fig. 9. Peridotite Plaza at the front of the Samani Town Office.

トが含まれる.この細粒結晶集合層や粒状のシンプレクタイ 卜は，ざくろ石の減圧分解によってできたと考えられてい る. したがって, このレルゾライトは, もともとざくろ石か んらん岩の安定領域にあったと考えられ，幌満かんらん岩体 の上昇履歴のなかで深さ約 50〜 $60 \mathrm{~km}$ の上部マントル情報 をもつ貴重な岩石タイプになっている(Tazaki et al., 1972; Takahashi and Arai, 1989; Ozawa and Takahashi, 1995; Takazawa et al., 1996).

(4) 斜長石レルゾライト(Fig. 9 の Q1, Q2) 幌満かんらん 岩体の岩石試料である. 主としてかんらん石, 直方輝石, 単 斜輝石，斜長石から構成される.

（5）ざくろ石直方輝石グラニュライト（Fig. 9 の V) 日高変 成帯, 幌別川の転石または, メナシュンベツ川支流の IV 帯 (グラニュライト相)の岩石試料である. 主としてざくろ石, 直方輝石, 斜長石, 石英から構成され, 片麻状構造が発達し ている. 径 $1 \mathrm{~cm}$ 程の自形のざくろ石斑状変晶が美しい.こ の岩石と同等の岩石は Osanai et al., (1991)や Komatsu et al. (1994) で記載されており, 時計回りの変成 $P-T-t$ 経路が 報告されている．幌別川上流のグラニュライト相岩石からは $19 \mathrm{Ma}$ のジルコン U-Pb 年代が得られている (Kemp et al., 2007).

(6) 縞状直方輝石片麻岩(Fig. 9 のU) 日高変成帯, メナ シュンベツ川支流の転石である。

（7）トーナル岩(Fig. 9 の M, N) 日高変成帯の岩石試料で ある，主として黒雲母，斜長石，石英から構成される，幌満 川または幌別川の転石, または様似町有牧野付近の段丘碟由 来の岩石試料と推定される. 中部ト一ナル岩と推定される.
(8)かんらん石斑れい岩(Fig. 9 の O, T) 日高変成帯の岩 石試料である. 主として斜長石, かんらん石, 単斜輝石から 構成される.幌満川上流部に東西約 $8 \mathrm{~km} \times$ 南北約 $10 \mathrm{~km}$ にわたつて分布するオピラルカオマップ岩体由来と推定され る.この岩石と同産地の岩石は, 本間(1997)で報告されて いる. オピラルカオマップ岩体は玄武岩質マグマから一連の 結晶作用によって形成されたもので, カルクアルカリ系列 (Motoyoshi, 1981), あるいはカルクアルカリ系列とソレ アイト系列に分類される(本間, 1997). この岩体に貫入する 花崗閃緑岩は $25.5 \pm 0.5 \mathrm{Ma}$ の Rb-Sr 鉱物アイソクロン年 代が知られている (Honma and Fujimaki, 1997).

(9) 斜長石レルゾライトと Type I (GB I) 苦鉄質岩の互層 (Fig. 9 の S), かんらん岩中の Type I(GB I) 苦鉄質岩(Fig. 9 のP) 幌満かんらん岩体中に観察される Type I(GB I) 苦鉄質岩の岩石試料である. 苦鉄質岩はいくつかの岩石夕イ プに識別されている. Type I(GB I) 苦鉄質岩は, 主として 斜長石, Tiに富む単斜輝石, かんらん石, 直方輝石, チ夕 ンパーガス閃石またはケルスート閃石, 緑色スピネル, チ夕 ン磁鉄鉱またはイルメナイト, 硫化物から構成される(新井 田・高澤, 2007). この岩石は Niida(1984), 塩谷・新井田 (1997), Takazawa et al.(1999)などで報告されている. 層厚が数 $10 \mathrm{~cm} \sim 1 \mathrm{~m}$ の規模の大きい Type I(GB I) 苦鉄質 岩は, 層の内部で極めて顕著な組成変化を示す (Niida, 1984). 層の中心部の原岩としてはざくろ石単斜輝石岩 (キュ ムレイト)が推定されている. またその周縁部は中央海嶺玄 武岩によく似た REE 含有量と同位体組成をもつマグマのメ ルト部分を代表すると考えられている(塩谷・新井田, 1997; 


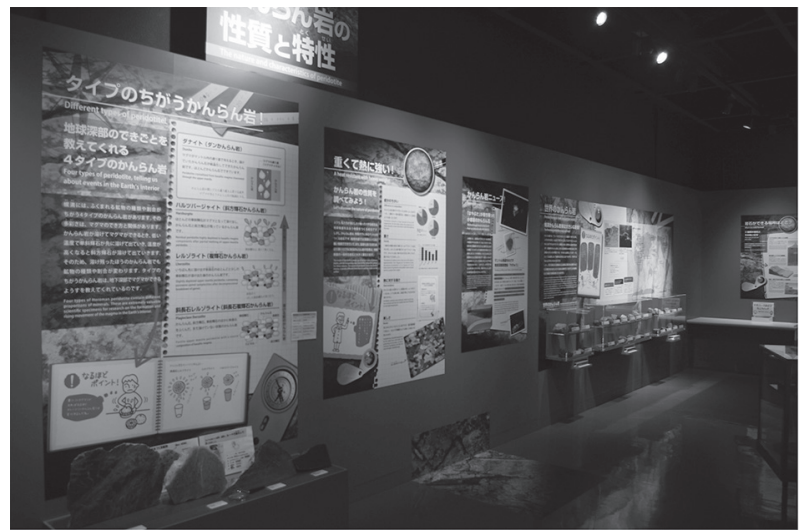

Fig. 10. Mt. Apoi Geopark Visitor Center.

Takazawa et al., 1999).

Stop 4 アポイ岳ジオパークビジターセンター [地形図] $1: 25,000$ 「様似」

[位 置 $] 42^{\circ} 6^{\prime} 42^{\prime \prime} \mathrm{N}, 142^{\circ} 59^{\prime} 19^{\prime \prime} \mathrm{E}$

[説明]アポイ山麓自然公園の中に，アポイ岳ジオパークビ ジターセンターがある. 2013 年にリニューアルし, アポイ 岳ジオパークの理解を深める展示, 情報提供を行っている. 展示室は延べ床面積 $406 \mathrm{~m}^{2}$ の 1 階建ての施設で，2つの展 示ソーンからなる.

入口には幅 $3 \mathrm{~m}$ の北海道中央部の鳥瞰図が展示されてい る. 地形と日高山脈形成史の関係について注目してほしい. 入館すると左側の赤色の壁のゾーンが，地球の鼓動を感じる (地球科学)ゾーン(Fig. 10), 右側の緑色の壁のゾーンが自 然と人々のかかわり (自然・歴史・産業)ゾーンである. 地球 科学ゾーンでは, 様似町周辺の大地のなりたちをテーマとし ている. 幌満かんらん岩体の代表的な標本や展示パネルか ら, 幌満かんらん岩体の特徴やかんらん岩の多様さとマグマ のでき方の関係について学習し, 偏光顕微鏡でのかんらん岩 薄片の観察, 世界のかんらん岩に関連する標本 23 個の観察, 展示パネルや映像「アポイ岳と日高山脈のなりたち」から日高 山脈形成史について学習することができる，また，日高変成 帯の花崗岩, 角閃岩, ホルンフェルス, シュードタキライト などを含む様似町周辺の代表的な岩石標本 26 個や, 様似町 冬島の日高主衝上断層剥ぎ取り標本などの観察をすることが できる.ほかにも様似町で見られる代表的な地形がジオラマ と展示パネルで紹介されており, 普段なにげなく見ている風 景は地球のダイナミックな変動でできたことを伝えている. 自然・歴史・産業ゾーンでは, 地質と自然・人々の暮らしの かかわりをテーマとしている. かんらん岩地域に咲くアポイ 岳固有の高山植物や, 北海道の中では古くから開けた様似町 の歴史的見どころなどを展示パネルやジオラマで紹介してい る.

\section{Stop 5 日高変成帯上部層片麻岩類と董青石トーナル岩} [地形図] $1: 25,000\lceil$ 庶野」

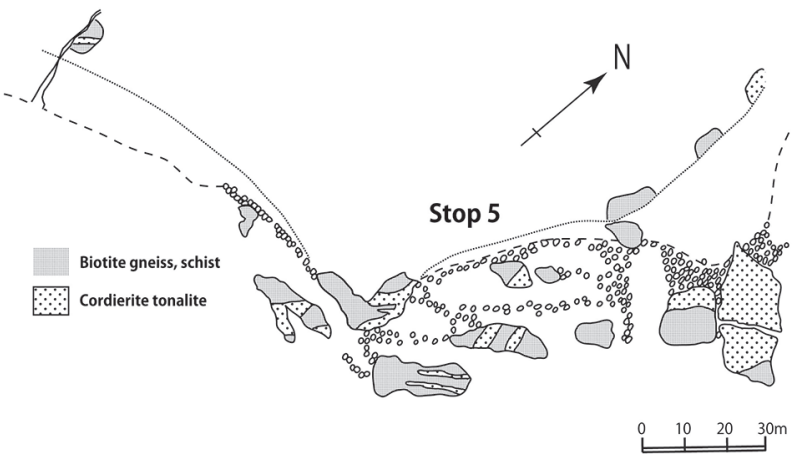

Fig. 11. Route map of the Ruran coast (Stop 5), after Komatsu et al. (1992).
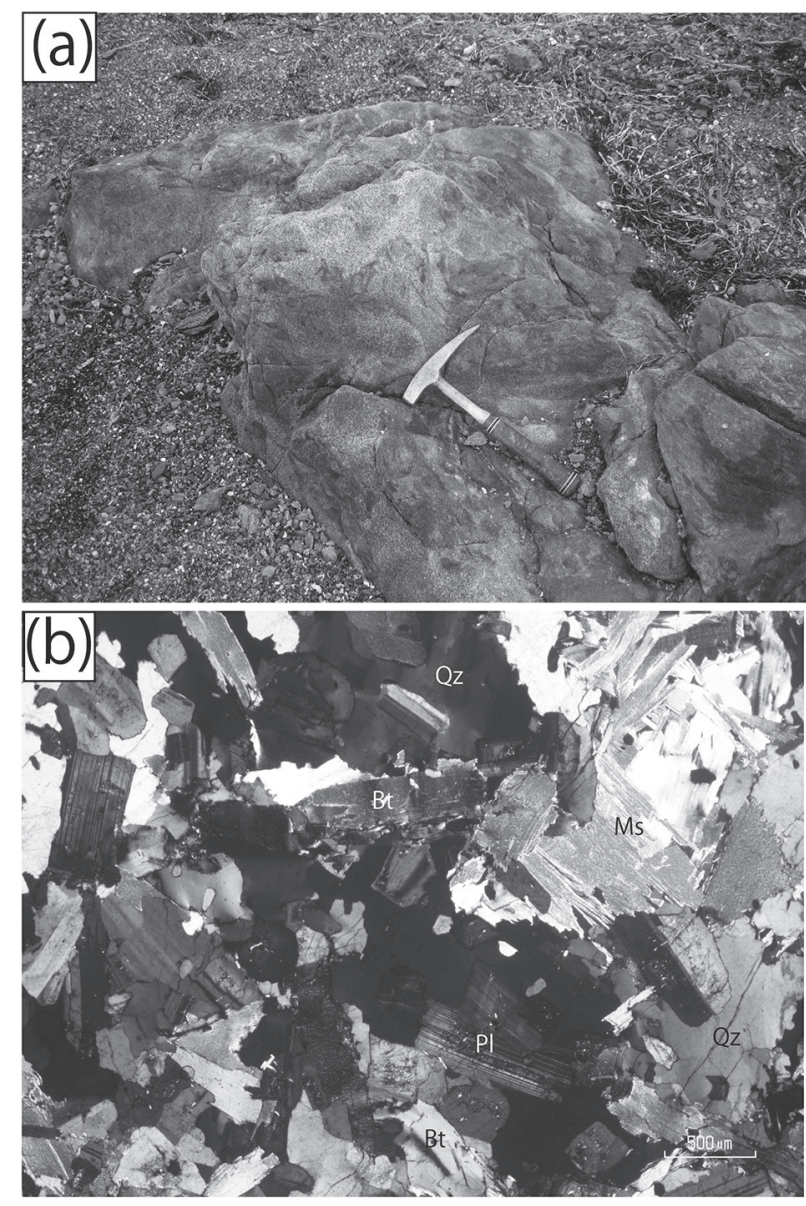

Fig. 12. (a) Cordierite tonalite with inclusions of biotite gneiss at the Ruran coast and (b) photomicrograph (crossed polarized light) of the cordierite tonalite.

\section{[位 置] $42^{\circ} 1^{\prime} 37^{\prime \prime} \mathrm{N}, 143^{\circ} 17^{\prime} 13^{\prime \prime} \mathrm{E}$ (Fig. 5c)}

[説明]えりも町庶野のルーラン〜千平 (チピラ)にかけての 海岸には, 上部変成岩層の黒雲母片麻岩および董青石トーナ ル岩が露出している (Fig. 11). 堇青石トーナル岩は黒雲母 片麻岩に貫入しており，片麻岩を包有し不均質な岩相を呈す る (Fig. 12a), 中一細粒, 塊状で, 黒雲母, 白雲母, 董青石, 石英, 斜長石からなる (Fig. 12b), 黒雲母片麻岩は, 黒雲 

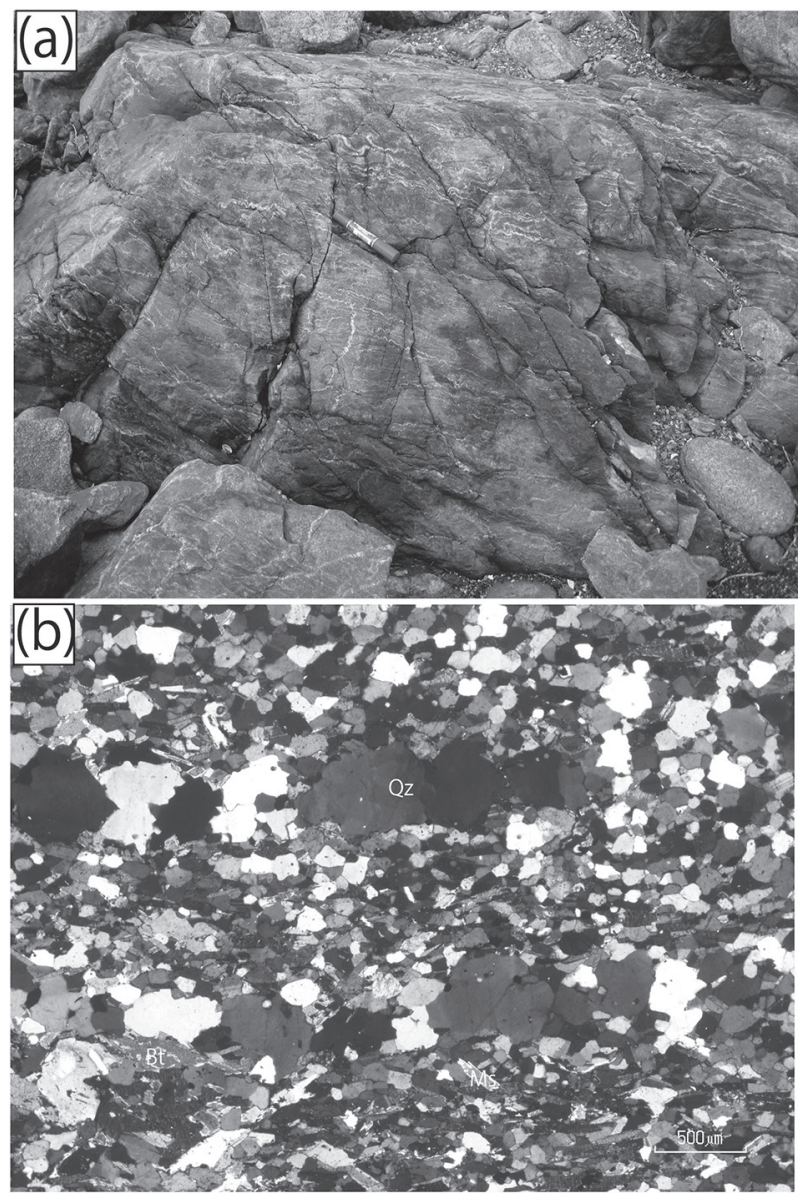

Fig. 13. (a) Banded biotite gneiss at the Ruran coast and (b) photomicrograph (crossed polarized light) of the biotite gneiss.

母, 白雲母, 斜長石, 石英からなり, 黒雲母の定向配列によ る面構造が発達している(Fig. 13b)。 また, 斜長石および石 英からなる優白質の縞状構造が発達している(Fig. 13a).

\section{Stop 6 音調津深成岩類}

[地形図] $1: 25,000$ 「日高目黒」,「音調津」

[位 置 $] 42^{\circ} 10^{\prime} 4^{\prime \prime} \mathrm{N}, 143^{\circ} 19^{\prime} 44^{\prime \prime} \mathrm{E}$ (Fig. 5d)

[説 明] 音調津周辺地域には苦鉄質岩〜珪長質岩までの多様 な深成岩類が分布する(Takahashi, 1983). 河野・植田 (1967) は黒雲母花崗閃緑岩から $36 \mathrm{Ma}$ の黒雲母 $\mathrm{K}-\mathrm{Ar}$ 年 代を報告した. Ishihara and Terashima(1985)はノーライ トから $35.3 \mathrm{Ma}$ の黒雲母 $\mathrm{K}-\mathrm{Ar}$ 年代を, 佐伯ほか (1995) は岩体近傍の黒雲母片岩や黒雲母ホルンフェルスから 34.9 〜34.5 Ma の黒雲母 $\mathrm{K}-\mathrm{Ar}$ 年代を報告している. 小島ほか (2015) は音調津地域のかんらん石斑れい岩類, ノーライト 〜閃緑岩類, 花崗閃緑岩類の全てから $37.2 \mathrm{Ma}$ のジルコン $\mathrm{U}-\mathrm{Pb}$ 年代を報告した。志村ほか (2015) は音調津地域の閃 緑岩中の泥質グラニュライト捕獲岩から, $37.8 \mathrm{Ma}$ のジル コン $\mathrm{U}-\mathrm{Pb}$ 年代を報告した.

この露頭は国道 336 号 (通称「黄金道路」)の脇にあり, 音

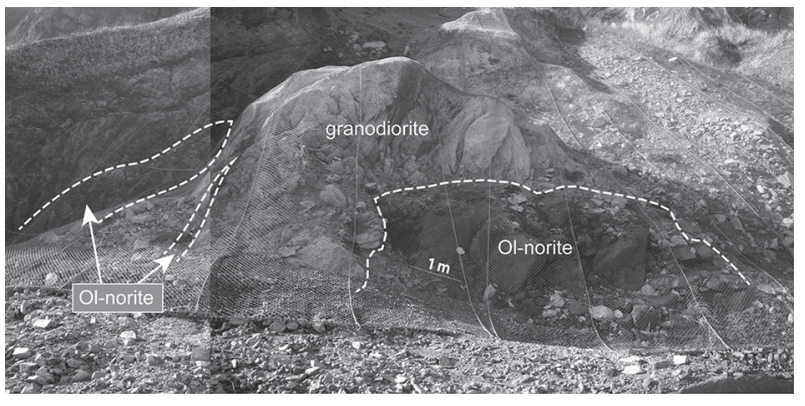

Fig. 14. Occurrence of olivine norite of the Oshirabetsu Plutonic Complex.

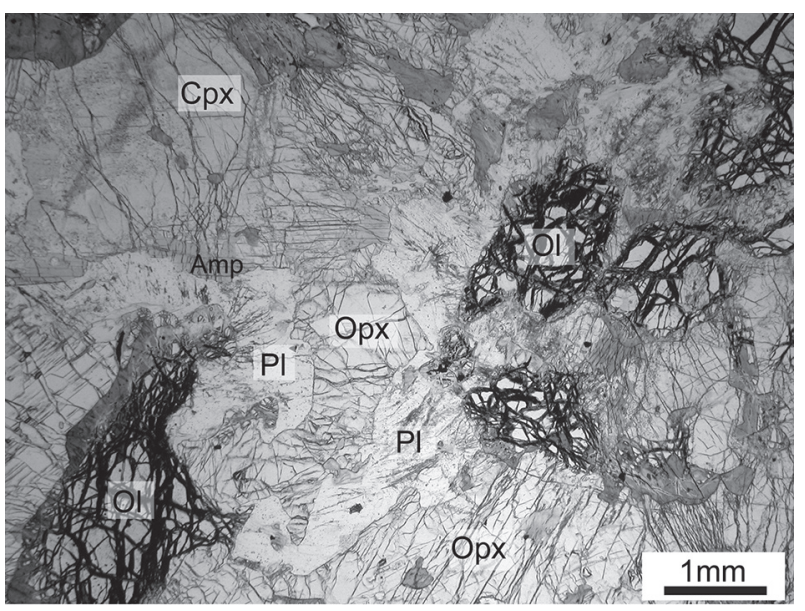

Fig. 15. Photomicrograph (plane polarized light) of the olivine norite.

調津地域の代表的な岩相 3 種類 (黒雲母花崗閃緑岩, 普通角 閃石閃緑岩, かんらん石ノーライト)などを見ることができ る. 音調津地域の露頭状況はあまり良くないが, 国道 336 号(通称「黄金道路」) 沿いの海岸線には好露頭が連続してい る. この露頭は落石の危険があるので, 各自ヘルメット等の 安全対策をしてほしい.

黒雲母花崗閃緑岩は明灰色粗粒〜中粒塊状 - 等粒状の岩石 で, 主要な構成鉱物は黒雲母, 斜長石, 石英, カリ長石であ る. まれに普通角閃石や白雲母を含む. 副成分鉱物としてア パタイト, ジルコン, モナズ石, チタン石, イルメナイトを 含む.

普通角閃石閃緑岩は，青灰色〜灰白色細粒塊状の岩石であ る. 黒雲母花崗閃緑岩と急冷縁を伴わずに接して産するか, 黒雲母花崗閃緑岩内の暗色包有岩 (Mafic Magmatic Enclave, MME）としてみられる. 岩体内に黒雲母片岩や石灰 珪質片岩を包有することがある. 主要構成鉱物は普通角閃 石, 黒雲母, 斜長石, 石英, イルメナイトで, 直方輝石や力 ミングトン閃石を含むことがある.

かんらん石ノーライトは, 黒色中粒塊状の岩石で, 黒雲母 花崗閃緑岩に対し syn-plutonic dyke 状に産する (Fig. 14). 主要構成鉱物はかんらん石, 直方輝石, 単斜輝石, 角閃石, 
金雲母，斜長石である(Fig. 15)，少量のクロム鉄鉱，磁鉄 鉱，イルメナイト，磁硫鉄鉱，ペントランド鉱，黄銅鉱を含 む．苦鉄質鉱物 (特にかんらん石) は変質し周囲に蛇紋石，緑 泥石を生じている.

\section{謝辞}

山口大学の大和田正明教授並びに新潟大学の高澤栄一教授 には査読をして頂き，多くの建設的なコメントを賜り，本論 は改善された. また, 編集委員の北海道大学, 竹下 徹教授 には，有益なご助言を賜つた. 以上の方々に厚くお礼申し上 げます。

\section{文献}

秋葉 力・ 木崎甲子郎・宮坂省吾・紺谷吉弘 (Akiba, C., Kizaki, K., Miyasaka, S. and Kontani, Y.), 1975, 5 万分の 1 地質図幅「上 豊似及及び同説明書 (Explanatory Text of the Geological Map of Japan Scale 1: 50.000, Kamitoyoni). 北海道立地下資源調 查所 (Geol. Surv. Hokkaido), 48p.

在田一則 - 森 裕 - 岡崎正次 - 小倉清春 - 本吉洋一(Arita, K., Mori, H., Okazaki, M., Ogura, K. and Motoyoshi, Y.), 1978, 日高 変成帯南部の変成岩類とミグマタイト類について(The metamorphic rocks and migmatites of the southern part of the Hidaka Metamorphic Belt). 地団研専報 (Monog. Assoc. Geol. Collab. Japan), 21, 27-41.

舟橋三男 - 猪木幸男 (Funahashi, M. and Igi, S.), 1956, 5 万分の 1 地質図幅「幌泉」及び同説明書 (Explanatory Text of the Geological Map of Japan Scale 1: 50.000, Horoizumi). 地質調査 所 (Geol. Surv. Japan), 64p.

橋本誠二(Hashimoto, S.), 1978, 北海道中軸帯の地質概観 (とくに 日高変成帯に関連して）（General views on the geology of the Axial Zone of Hokkaido, with special reference to the Hidaka Metamorphic Belt)*. 地団研専報 (Monog. Assoc. Geol. Collab. Japan), 21, 1-8.

橋本誠二・武田裕幸 (Hashimoto, S. and Takeda, H.), 1960, 5 万 分の 1 地質図幅「広尾」及び同説明書 (Explanatory Text of the Geological Map of Japan Scale 1: 50.000, Biroo). 北海道立 地下資源調查所 (Geol. Surv. Hokkaido), 40p.

本間 寿 (Honma, H.), 1997, 日高変成帯南部オピラルカオマップ複 合深成岩体の岩石学的特徵(Petrological characteristics of Opirarukaomappu plutonic complex in the southern Hidaka metamorphic belt, Hokkaido, Japan). 地質学論集 (Mem. Geol. Soc. Japan), 47, 43-55.

Honma, H. and Fujimaki, H., 1997, Rb-Sr dating and petrological characteristics of a granodiorite dike from the southern Hidaka metamorphic belt, Hokkaido, Japan. Jour. Mineral. Petrol. Econ. Geol., 92, 265-272.

Ishihara, S. and Terashima, S., 1985, Cenozoic granitoids of central Hokkaido, Japan - An example of plutonism along a collisional belt. Bull. Geol. Surv. Japan, 36, 653-680.

Jahn, B. M., Usuki, M., Usuki, T. and Chung, S. L., 2014, Generation of Cenozoic granitoids in Hokkaido(Japan): Constraints from zircon geochronology, Sr-Nd-Hf isotopic and geochemical analyses, and implications for crustal growth. Amer. Jour. Sci., 314, 704-750.

Kaneoka, I, Takahashi, N. and Arai, S., 2001, ${ }^{40} \mathrm{Ar}-{ }^{39} \mathrm{Ar}$ analysis of phlogopite in the Horoman Peridotite Complex, Hokkaido, Japan and implications for its origin. Island Arc, 10, 2232.

河野義礼・植田良夫 (Kawano, Y. and Ueda, Y.), 1967, 本邦火成岩 の $\mathrm{K}-\mathrm{Ar}$ dating $(\mathrm{VI})$ - 花崗岩類, 総括 $-(\mathrm{K}-\mathrm{Ar}$ dating on the igneous rocks in Japan (IV)_Granitic rocks, summary-). 岩 石鉱物鉱床学会誌 (Jour. Japan. Assoc. Mineral. Petrol. Econ. Geol.), 57, 177-187.

Kemp, A. I. S. and Shimura, T., 2006, Ion microprobe U-Pb (zircon) geochronology of the Hidaka Metamorphic Belt, Hokkaido, Japan: New results and implications for granitic generation at convergent margins. 19th Gen. Meet. Int. Mineral. Assoc., Abstr., 322.

Kemp, A. I. S., Shimura, T. and Hawkesworth, 2007, Linking granulites, silicic magmatism, and crustal growth in arcs: Ion microprobe (zircon) $\mathrm{U}-\mathrm{Pb}$ ages from the Hidaka metamorphic belt, Japan. Geology, 35, 807-810.

Kimura, G., 1986, Oblique subduction and collision : Forearc tectonics of the Kuril arc. Geology, 14, 404-407.

Kimura, G., 1996, Collision orogeny at arc-arc junctions in the Japanese Islands. Island Arc, 5, 262-275.

木村学・楠 香織 (Kimura, G. and Kusunoki, K.), 1997, 日高造山 運動と島弧会合部のテクトニクス (The Hidaka Orogeny and tectonics of arc-arc junction). 地質学論集 (Mem. Geol. Soc. Japan), 47, 295-305.

小島 萌・Kemp, A. I. S. · 大橋美由希・志村俊昭 (Kojima, M., Kemp, A. I. S., Ohashi, M. and Shimura, T.), 2015, 日高変成 帯の形成テクトニクス (2) : 二度の火成活動 (Evolution of the Hidaka Metamorphic Belt, part II: Dual magmatism). 日本 地質学会第 122 年学術大会講演要旨 (122th Ann. Meet. Geol. Soc. Japan, Abstr.), 65

小島 萌 - 志村俊昭 (Kojima, M. and Shimura, T.), 2014, 日高変成 帯, 札内川七ノ沢における I タイプ・S タイプトーナル岩マグマ の起源 : $\mathrm{Sr} \cdot \mathrm{Nd}$ 同位体比からの検討 (Origin of the I-and Stype tonalitic magma in the Satsunai-gawa Shichino-sawa river region of the Hidaka metamorphic belt, Hokkaido, northern Japan). 地質雑(Jour. Geol. Soc. Japan), 120, 393412.

小松正幸 (Komatsu, M.) , 1977, 固体併入型かんらん岩とオフィオ ライト (Solid-intrusive Peridotites Related to Ophiolites). 月 刊海洋科学 (Marine Sci. Monthly), 8, 65-70.

小松正幸・宮下純夫 - 在田一則 (Komatsu, M., Miyashita, S. and Arita, K.), 1986, 日高変成帯の構成 (Composition and structure of the Hidaka metamorphic belt, Hokkaido-historical review and present status). 地団研専報 (Monog. Assoc. Geol. Collab. Japan), 31, 189-203.

Komatsu, M., Miyashita, S., Maeda, J., Osanai, Y. and Toyoshima, T., 1983, Disclosing of a deepest section of continentaltype crust up-thrust as the final event of collision of arcs in Hokkaido, North Japan. In Hashimoto, M. and Uyeda, S., eds., Accretion Tectonics in the Circum-Pacific Regions, TERRAPUB, Tokyo, 149-165.

Komatsu, M., Osanai, Y., Toyoshima, T. and Miyashita, S., 1989, Evolution of the Hidaka metamorphic belt, northern Japan. In Daly, J. S., Cliff, R. A. and Yardley, B. W. D., eds., Evolution of Metamorphic Belts, Geol. Soc. Spec. Publ., 43, 487-493.

Komatsu, M., Toyoshima, T., Osanai, Y. and Arai, M., 1994, Prograde and anatectic reactions in the deep arc crust exposed in the Hidaka metamorphic belt, Hokkaido, Japan. Lithos, 33, 31-49.

Komatsu, M., Shibakusa, H., Miyashita, S., Ishizuka, H., Osanai, Y. and Sakakibara, M., 1992, Subduction of collision related high and low $\mathrm{P} / \mathrm{T}$ metamorphic belts in Hokkaido. 29th IGC Field Trip Guide Book, C01, Geol. Soc. Japan, $1-61$.

黒田吉益・田崎耕市 (Kuroda, Y. and Tasaki, K.), 1969, 変成帯の 超塩基性岩類 (Origin of Ultrabasic Rocks in the Metamorphic Zones in Japan). 地質学論集 (Mem. Geol. Soc. Japan) 4, 99-108.

松井 愈 - 佐藤博之 - 小坂利幸 - 宮坂省吾 - 笹島征士郎 - 秋葉 力...... 春日井昭(Matsui, M., Sato, H., Kosaka, T., Miyasaka, S., Sasajima, S., Akiba, C.,..., Kasugai, A.), 1974, 大樹地域の地 質. 地域地質研究報告 (5 万分の 1 地質図幅) (Geology of the Taiki District. With Geological Sheet Map at 1: 50,000). 地 質調查所 (Geol. Surv. Japan), 69p.

宮下純夫(Miyashita, S.), 1983, 日高変成帯西帯におけるオフィオ 
ライト層序の復元 (Reconstruction of the ophiolite succession in the western zone of the Hidaka Metamorphic Belt, Hokkaido.). 地質雑 (Jour. Geol. Soc. Japan), 89, 69-86.

Miyashita, S., Niida, K., 1981, Metamorphosed Dolerite Intrusives from the Western Zone of the Hidaka Metamorphic Belt, Hokkaido. Jour. Fac. Sci. Hokkaido Univ., Ser. IV, 20, $113-133$.

Motoyoshi, Y., 1981, Fe-Ti Oxide minerals in the Horoman Plutonic Complex of the Hidaka metamorphic belt, Hokkaido. Jour. Fac. Sci. Hokkaodo Univ., Ser. IV, 20, 87-94.

七山 太(Nanayama, F.) , 1992, 北海道中軸部, 日高帯・中の川層群 において認められる 3 帯の petroprovince とその意義(Three petroprovinces identified in the Nakanogawa Group, Hidaka Belt, central Hokkaido, Japan, and their geotectonic significance). 地質学論集 (Mem. Geol. Soc. Japan), 38, 27-42.

七山 太 - 雁澤好博 (Nanayama, F. and Ganzawa, Y.), 1997, 日高 帯中の川層群北部ユニットの堆積層序, 堆積環境および堆積年代 (Sedimentary stratigraphy, environment and age of the northern unit of Nakanogawa Group in the Hidaka belt, central Hokkaido, Japan). 地質学論集 (Mem. Geol. Soc. Japan), 47, 279-293.

Nanayama, F., Takahashi, Y., Yamasaki, T., Nakagawa, M., Iwano, H. and Danhara, T., 2018, LA-ICP-MS U-Pb zircon ages of the Nakanogawa Group in the southern Hidaka belt and implications for its provenance and protolith of the Hidaka metamorphic rocks. Island Arc, 27, e12234.

Niida, K., 1974, Structure of the Horoman ultramafic massif of the Hidaka metamorphic belt in Hokkaido, Japan. Jour. Geol. Soc. Japan, 80, 31-44.

Niida, K. 1984, Petrology of the Horoman ultramafic rocks in the Hidaka metamorphic belt, Hokkaido, Japan. Jour. Fac. Sci., Hokkaido Univ., Ser. IV, 21, 197-250.

新井田清信 ・高澤栄一(Niida, K. and Takazawa, E.), 2007, 幌満か んらん岩体の層状構造とその起源 (Origin of layering observed in the Horoman peridotite complex, Japan). 地質雑 (Jour. Geol. Soc. Japan), 113 (Supplement), 167-184.

小野昌子 (Ono, M.), 2002, フィッション・トラック法からみた日高 山脈の隆起時期 (Uplift history of the Hidaka Mountains: Fission-track analyses). 地震研究所彙報 (Bull. Earthq. Res. Inst. Univ. Tokyo), 77, 123-130.

小山内康人 (Osanai, Y.), 1985, 静内川上流地域における日高変成帯 主帯変成岩類の地質と変成分帯 (Geology and metamorphic zoning of the Main Zone of the Hidaka Metamorphic Belt in the Shizunai River region, Hokkaido). 地質雑 (Jour. Geol. Soc. Japan), 91, 259-278.

Osanai, Y., Arita, K. and Banba, M., 1986, P-T conditions of granulite-facies rocks from the Hidaka Metamorphic Belt, Hokkaido, Japan. Jour. Geol. Soc. Japan, 92, 793-808.

Osanai, Y., Komatsu, M. and Owada, M., 1991, Metamorphism and granite genesis in the Hidaka Metamorphic Belt, Hokkaido, Japan. Jour. Metamorphic Geol., 9, 111-124.

小山内康人 - 宮下純夫 - 在田一則 - 番場光隆 (Osanai, Y., Miyashita, S., Arita, K. and Banba, M.), 1986, 大陸地殼一海洋地殼接 合衝上体における変成作用と温度・圧力構造一日高変成帯主帯・ 西帯の例 - (The metamorphism and thermal structure of the collision terrain of a continental and oceanic crusts: a case study of the Hidaka metamorphic belt, Hokkaido, Japan). 地団研専報 (Monog. Assoc. Geol. Collab. Japan), 31, 205222.

Osanai, Y. and Owada, M., 1990, Finding of staurolite in pelitic granulites from the Hidaka metamorphic belt, Hokkaido, Japan. Jour. Geol. Soc. Japan, 96, 549-552.

Osanai, Y., Owada, M. and Kawasaki, T., 1992, Tertiary deep crustal ultrametamorphism in the Hidaka metamorphic belt, northern Japan. Jour. Metamorphic Geol., 10, 401-414.

小山内康人 · 大和田正明 - 志村俊昭 - 中野伸彦 - 川浪聖志 - 小松正 幸 (Osanai, Y., Owada, M., Shimura, T., Nakano, N., Kawanami, S. and Komatsu, M.), 2006, 日高島弧 (日高変成帯主帯)
下部地殼における高度変成岩の部分溶融(Partial melting of high-grade metamorphic rocks in lower crustal part of the Hidaka Arc (Main Zone of the Hidaka metamorphic belt), northern Japan). 地質雑 (Jour. Geol. Soc., Japan), 112, 623638.

小山内康人 - 大和田正明 - 高須岩夫 (Osanai, Y., Owada, M. and Takasu, I.), 1989, 日高変成帯主帯変成岩類の原岩構成 (Original rock constitution of the Main Zone of the Hidaka metamorphic belt, Hokkaido, Japan). 福岡教育大学紀要 (Bull. Fukuoka Univ. Educ.), Part III, 38, 71-91.

大和田正明 (Owada, M.) , 1989, 日高変成帯主帯南端部に分布する 花崗岩類の地質及び化学組成一特に含董青石花崗岩類について - (Geology and chemical composition of granitic rocks in the southern part of the Hidaka metamorphic belt, with special reference to cordierite bearing granitic rocks), 地質雑 (Jour. Geol. Soc., Japan), 95, 227-240.

大和田正明 - 小山内康人 (Owada, M. and Osanai, Y.), 1989, 日高 変成帯における花崗岩類の成因 (Genesis of granitic rocks in the Hidaka metamorphic belt)*. 月刊地球 (Chikyu Monthly), $11,252-257$.

Owada, M., Osanai, Y. and Kagami, H., 1991, Timing of anatexis in the Hidaka metamorphic belt, Hokkaido, Japan. Jour. Geol. Soc. Japan, 97, 751-754.

大和田正明 - 小山内康人 - 加々美寛雄 (Owada, M., Osanai, Y. and Kagami, H.), 1992, 地殼深部における花崗岩質マグマの形成と その時期一日高変成帯主帯の例 (Formation of granitic magma in deep crust and its timing-An example of the Hidaka metamorphic belt)*. 月刊地球 (Chikyu Monthly), 14, 291-295.

Owada, M., Osanai, Y. and Kagami, H., 1997, Rb-Sr isochron ages for hornblende tonalite from the southeastern part of the Hidaka metamorphic belt, Hokkaido, Japan: Implications for timing of peak metamorphism. Mem. Geol. Soc. Japan, 47, 21-27.

Owada, M., Osanai, Y., Shimura, T., and Toyoshima, T., 2003, Crustal section and anatexis of lower crust due to mantle flux in the Hidaka metamorphic belt, Hokkaido, Japan. Geol. Surv. Japan, Interim-Rep., 28, 81-102.

大和田正明 - 山崎 徹 - 小山内康人 - 吉本一峰 - 濱本拓志 - 加々美寛 雄 (Owada, M., Yamasaki, T., Osanai, Y., Yoshimoto, K., Hamamoto, T. and Kagami, H.), 2006, 日高変成帯野塚岳地 域, 二オベツ岩体の貫入による中新世の複変成作用, 部分溶融お よび花崗岩マグマの形成(Poly-metamorphism, anatexis and formation of granitic magma due to intrusion of the Niobetsu complex during Miocene, the Nozuka-dake area, Hidaka metamorphic belt, northern Japan). 地質雑(Jour. Geol. Soc. Japan), 112, 666-683.

Ozawa, K. and Takahashi, N. 1995, P-T history of a mantle diapir: the Horoman peridotite complex, Hokkaido, northern Japan. Contrib. Mineral. Petrol., 120, 223-248.

Research Group of Peridotite Intrusion, 1967, Ultrabasic rocks in Japan. Jour. Geol. Soc. Japan, 73, 543-553.

佐伯圭右・柴 正敏・板谷徹丸 - 大貫 仁 (Saeki, K., Shiba, M., Itaya, T. and Onuki, H.) , 1995, 北海道, 日高帯南部における変成 岩及び深成岩の $\mathrm{K}-\mathrm{Ar}$ 年代とその意味 $(\mathrm{K}-\mathrm{Ar}$ ages of the metamorphic and plutonic rocks in the southern part of the Hidaka belt, Hokkaido and their implications). 岩 鉱(Jour. Mineral. Petrol. Econ. Geol.), 90, 297-309.

志村俊昭 (Shimura, T.) , 1992, 花雴岩質マグマの迸入と日高変成帯 の衝上テクトニクス (Intrusion of granitic magma and uplift tectonics of the Hidaka metamorphic belt, Hokkaido). 地質 雑 (Jour. Geol. Soc. Japan), 98, 1-20.

志村俊昭 - 小島 萌 - Kemp, A. I. S. (Shimura, T., Kojima, M. and Kemp, A. I. S.) , 2015, 日高変成帯の形成テクトニクス (1) : 二 度の変成作用と地款の二重構造 (Evolution of the Hidaka Metamorphic Belt, part I: Dual metamorphism and duplicate crust). 日本地質学会第 122 年学術大会講演要旨 (122th Annu. Meet. Geol. Soc. Japan, Abstr.), 64.

Shimura, T., Komatsu, M. and Iiyama, J. T., 1992, Genesis of 
the lower crustal Grt-Opx tonalite (S-type) in the Hidaka Metamorphic Belt, northern Japan. Trans. Roy. Soc. Edinburgh, Earth Sci., 83, 259-268.

Shimura, T., Owada, M., Osanai, Y., Komatsu, M. and Kagami, H., 2004, Variety and genesis of the pyroxene-bearing Sand I-type granitoids from the Hidaka Metamorphic Belt, Hokkaido, northern Japan. Trans. Roy. Soc. Edinburgh, Earth Sci., 95, 161-179.

塩谷由美・新井田清信 (Shiotani, Y. and Niida, K.), 1997, 幌満か んらん岩体の苦鉄質岩層の起源 (Origin of mafic layers in the Horoman peridotite complex). 地質学論集 (Mem. Geol. Soc. Japan), 47, 123-137.

Takahashi N., 1992, Evidence for melt segregation towards fractures in the Horoman mantle peridotite complex. $\mathrm{Na}$ ture, 359, 52-55.

Takahashi, N. and Arai, S., 1989, Textural and chemical features of chromian spinel-pyroxene symplectites in the Horoman peridotites, Hokkaido, Japan. Sci. Rep. Inst. Geosci. Univ. Tsukuba. Sec. B, Geol. Sci., 10, 45-55.

Takahashi, T., 1983, The Oshirabetsu Gabbroic Mass in the southeastern part of the Hidaka metamorphic belt, Hokkaido, Japan. Jour. Fac. Sci., Hokkaido Univ., Ser. IV, 20, 203224.

高橋 浩 (Takahashi, Y.), 1992, 日高変成帯主帯札内川上流地域の トーナル岩類の岩石学的研究-S-タイプ / I- タイプ花崗岩類の 共存関係 - (Petrological study of tonalitic rocks in the upper reaches of Satsunai River, Main Zone of the Hidaka Metamorphic Belt -Coexistent relation of S-type with I-type granite-). 地質雑(Jour. Geol. Soc. Japan), 98, 295-308.

高橋 浩 - 七山 太・山崎 徹 - 岩野英樹 - 檀原 徹 - 平田岳史 (Takahashi, Y., Nanayama, F., Yamasaki, T., Iwano, H., Danhara, T. and Hirata, T.), 2017, 日高変成带上部層変成岩類のジルコン $\mathrm{U}-\mathrm{Pb}$ 年 代(Zircon U-Pb ages of the Hidaka metamorphic rocks in the upper sequence of the Hidaka metamorphic belt). 日本地質学会第 124 年学術大会講演要旨 (124th Ann. Meet. Geol. Soc. Japan, Abstr.), 63.

Takazawa, E. Frey, F., Shimizu, N. and Obata, M., 1996, Evolution of the Horoman Peridotite (Hokkaido, Japan): Implications from pyroxene compositions. Chem. Geol., 134, 3-26.

Takazawa, E., Frey, F. A., Shimizu, N. and Obata, M., 2000, Whole rock compositional variations in an upper mantle peridotite (Horoman, Hokkaido, Japan): are they consistent with a partial melting process?. Geochim. Cosmochim. Acta, 64. 695-716.

Takazawa, E., Frey, F. A., Shimizu, N., Saal, A. and Obata, M., 1999, Polybaric petrogenesis of mafic layers in the Horoman peridotite complex, Japan. Jour. Petrol., 40, $1827-$ 1851.

Tazaki, K., Ito, E. and Komatsu, M., 1972, Experimental study on a pyroxene-spinel symplectite at high pressures and temperatures. Jour. Geol. Soc. Japan, 78, 347-354.
豊島剛志・小松正幸・志村俊昭 (Toyoshima, T., Komatsu, M. and Shimura, T.), 1997, 日高変成帯の形成テクトニクス (Tectonics of the Hidaka metamorphic belt, Hokkaido, northern Japan). 地質学論集 (Mem. Geol. Soc. Japan), 47, 259-277.

Ueda, H., 2016, Hokkaido. In Moreno, T., Wallis, S., Kojima, T. and Gibbons, W. eds., The Geology of Japan. Geol. Soc., London, 201-221.

Usuki, T., Kaiden, H., Misawa, K. and Shiraishi, K., 2006, Sensitive high-resolution ion microprobe $\mathrm{U}-\mathrm{Pb}$ ages of the latest Oligocene-early Miocene rift-related Hidaka high temperature metamorphism in Hokkaido, northern Japan. Island Arc, 15, 503-516.

Whitney, D. L. and Evans, B., 2010, Abbreviations for names of rock-forming minerals. Amer. Mineral., 95, 185-187.

Yoshikawa, M., Nakamura, E. and Takahashi, N., 1993, Rb-Sr isotope systematics in a phlogopite-bearing spinel lherzolite and its implications for age and origin of metasomatism in the Horoman peridotite complex, Hokkaido, Japan. Jour. Mineral. Petrol. Econ. Geol., 88, 121-30.

[URL1] Kemp, T. and Shimura, T., Zircon U-Pb (\& Lu-Hf) isotope geochronology of the Hidaka Metamorphic Belt, Hokkaido, NE Japan, http://www.geosci.ed.ac.uk/facilities/ionprobe/Posters/Posters.html

* English translation from the original written in Japanese
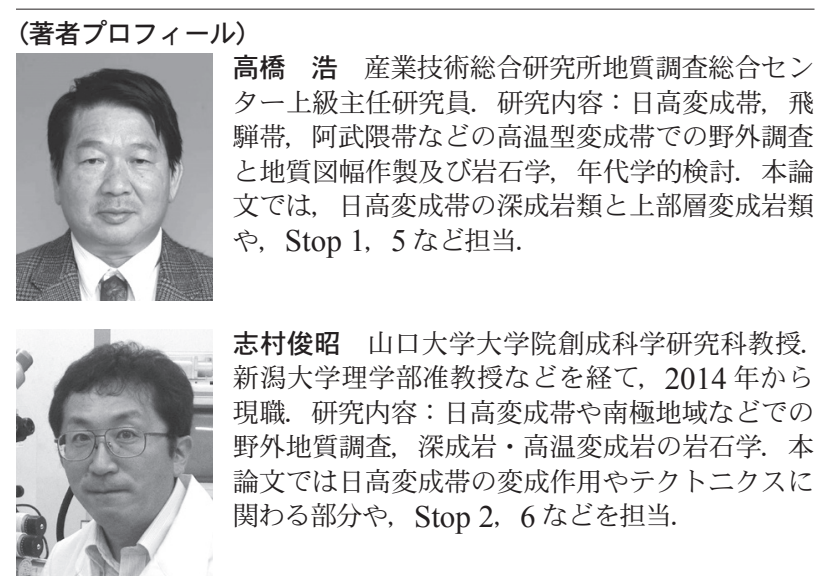

志村俊昭 山口大学大学院創成科学研究科教授. 新潟大学理学部准教授などを経て，2014 年から 現職. 研究内容：日高変成帯や南極地域などでの 野外地質調査, 深成岩・高温変成岩の岩石学. 本 論文では日高変成帯の変成作用やテクトニクスに 関わる部分や，Stop 2, 6 などを担当.

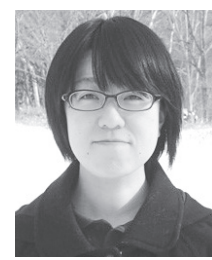

加藤聡美 アポイ岳ジオパークビジターセンター 学芸員. 2012 年から現職. 研究内容：北部日高 帯現地性緑色岩の発泡に関する岩石学的研究. 様 似町近郊の野外地質調査. 本論文では Stop3, 4 を担当.

科学論文では, 学説の検証可能性を保証することが重要です。そのため, 地質学雑誌掲載論文には, 重 要な証拠となった試料がごこで得られたかを示しているものがあります。言うまでもないことですが, 見学や採取を行う場合, 各自の責任において地権者や関係官庁への連絡と許可の取得の必要があること にご注意下さい。詳しくは，以下のサイトをご覧ください.

http://www.geosociety.jp/publication/content0073.html 